\title{
Prairie dog effects on harvester ant species diversity and density
}

\author{
JUSTIN E. KRETZER AND JACK F. CULLY, JR.
}

Authors are a graduate student in the Division of Biology and Assistant Unit leader, Kansas Cooperative Fish \& Wildlife Research Unit, USGS-BRD, Division of Biology, Kansas State University, Manhattan, Kan. 66506.

\begin{abstract}
The purpose of this study was to determine if black-tailed prairie dogs (Cynomys ludovicianus Ord) influence harvester ant nest density and species composition within the shortgrass prairie biome of southwestern Kansas. Two treatments were established: areas colonized by prairie dogs and areas not colonized by prairie dogs. We recorded 183 harvester ant nests of 3 species. Harvester ant nest density did not differ significantly between prairie dog colonies (3.08 nests ha ${ }^{-1}$ ) and non-colonized shortgrass prairie sites (4.54 nests ha ${ }^{-1}$ ), but species composition did. Pogonomyrmex rugosus Emery was the most frequent species on prairie dog colonies where it accounted for $87 \%$ of ant nests present, as opposed to $33 \%$ on sites where prairie dogs were absent. Pogonomyrmex barbatus Smith was the most abundant species on non-colonized areas, making up $49 \%$ of the ant nests sampled. Pogonomyrmex occidentalis Cresson comprised $11 \%$ of ant nests sampled, and was nearly absent from prairie dog colonies (20 nests on non-colonized sites vs. 1 nest on prairie dog colonies). The average number of harvester ant species found per site was consistently greater on sites where prairie dogs were absent.
\end{abstract}

Key Words: Cynomys ludovicianus, Pogonomyrmex, diversity, shortgrass prairie, Kansas

Harvester ants (Pogonomyrmex spp.) are widespread in the arid and semi-arid regions of western North America. Harvester ants are locally abundant and are considered pests in rangelands where densities are high. These ants may alter plant community structure by denuding vegetation and harvesting seeds and litter surrounding colonies (Rogers and Lavigne 1974). Hewitt et al. (1974) state that harvester ants have the most consistent impact on rangeland of any insect other than grasshoppers. Ants also are considered important contributors to soil formation (Rogers and Lavigne 1974). Because earthworms are not abundant in semiarid rangelands, the ant is the most important invertebrate that moves soil vertically (Jacot 1936).

Black-tailed prairie dogs (Cynomys ludovicianus Ord) are native herbivores that are capable of dramatically altering grassland habitats (King 1955, Koford 1958, Hoogland 1995, Winter 1999) and are considered by some to be keystone species (Miller et al. 1994, Wuerthner 1997, Kotliar et al. 1999). Because of serious declines in the past, and ongoing declines over large portions

We were assisted in the field by Dwayne Winslow. Bobby Brown confirmed ant species identification, and Jeffrey Pontius provided valuable statistical advice. Research was funded by the U.S.D.I. Fish and Wildlife Service, U.S.D.A. Forest Service, and Kansas State University.

Manuscript accepted 18 Apr. 2000

\section{Resumen}

El propósito de este estudio fue determinar si los perros de la pradera (Cynomys ludovivianus Ord.) influyen en la densidad y diversidad de especies de hormigas cosechadoras de la bioma de praderas de zacates cortos del sudoeste de Kansas. Se establecieron dos tratamientos: áreas colonizadas por perros de la pradera y áreas no colonizadas. Registramos 183 hormigueros de 3 especies de hormigas cosechadoras. La densidad de hormigas cosechadoras no difirió significativamente entre las áreas colonizadas por perros de la pradera (3.08 hormigueros ha' $\left.{ }^{-1}\right)$ y las no colonizadas (4.54 hormigueros $\mathrm{ha}^{-1}$ ), pero la composición de especies si difirió. La especie de hormiga Pogonomyrmex rugosus Emery fue la más frecuente en las áreas colonizadas por perros de la pradera en la que el $87 \%$ de los hormigueros registrados fueron de esta especie, en contraste con el $33 \%$ de los hormigueros de los sitios donde los perros de la pradera estuvieron ausentes. La especie de hormiga Pogonomyrmex barbatus Smith fue la más abundante en las áreas no colonizadas con el 49\% de los hormigueros muestreados. La especie Pogonomyrmex occidentalis Cresson comprendió el $\mathbf{1 1 \%}$ de los hormigueros y estuvo casi ausente en las colonias de perros de la pradera ( 20 hormigueros en las áreas no colonizadas vs.1 en las áreas colonizadas). El promedio del número de especies de hormigas cosechadoras encontradas por sitio fue consistentemente mayor en los sitios donde los perros de la pradera estuvieron ausentes.

of their range, the Fish and Wildlife Service conducted a status review of black-tailed prairie dogs that found the species warranted but precluded for listing under the Endangered Species Act (USDI 2000).

In addition to alterations in vegetative communities, black-tailed prairie dog activities can cause significant changes in the species composition and densities of a variety of vertebrate groups occupying mixed-grass prairie habitats (O'Meilia et al. 1982, Agnew et al. 1986); however, there currently are only a few detailed studies describing the influence of prairie dogs on invertebrate communities. In mixed-grass prairies of South Dakota, total density of soil nematodes was higher in prairie dog colonies than in uncolonized sites (Ingham and Detling 1984). Conversely, in northern Oklahoma, arthropod biomass was lower on prairie dog colonies than on uncolonized areas (O'Meilia et al. 1982).

The purpose of this research was to determine if black-tailed prairie dogs influence harvester ant (Pogonomyrmex spp.) species composition and nest density. We documented the density and species composition of harvester ant nests at study sites on and off black-tailed prairie dog colonies at the Cimarron National Grassland, Kans. 


\section{Methods}

This study was conducted on the Cimarron National Grasslands in Morton County, Kans. (Latitude $37^{\circ} 07^{\prime} \mathrm{N}-$ Longitude $102^{\circ} 00^{\prime} \mathrm{W}$ ), during July 1997. Two treatments were established with 5 sample sites each scattered across the northern half of the grassland: areas colonized by prairie dogs and areas of similar habitat not colonized by prairie dogs. We selected 5 prairie dog colonies, which varied in size from 30 to 54 ha. These sites were selected because they were among the largest prairie dog colonies on the grasslands. Five non-colonized study sites, which varied in size from 32 to 65 hectares were selected in pastures with slope and vegetation similar to the prairie dog sites, but without prairie dogs. All study sites were shortgrass community type dominated by buffalograss (Buchloe dactyloides (Nutt.) Engelm.) and blue grama (Bouteloua gracilis (H.B.K.) Lag. Ex Griffiths), with low topographic relief. Soil types at all sites were characterized by loamy and silty-loam soils in the Richfield (fine, smectite, mesic Aridic, Arguistolls)_Ulysses (fine-silty, mixed, superactive, mesic Aridic, Haplustolls) association with slopes between 0-6\% (Dickey et al. 1963).

Livestock was managed on the Cimarron National Grasslands under rotational grazing, with intensity adjusted to the available forage; therefore, not all study sites were grazed at the same time each year. One prairie dog colony, and 2 non-colonized sites were not grazed by livestock during 1996 or 1997 . The combination of prairie dogs and livestock creates a situation where grazing intensity and soil disturbance may be very high.

Prairie dog burrow density was calculated at each colony using a plotless density estimator modified from Cook and Stubbendieck (1986). Because nearest neighbor estimates of density are appropriate only for randomly distributed objects, and we have evidence that prairie dog burrows are regularly dispersed (Cully, unpublished data), we adapted a point to burrow estimator as follows. One hundred meter long tapes were laid at random at 8 locations in each colony. Random points were selected in each $10 \mathrm{~m}$ section of the tape for 75 points at each colony. The distance from the random point to the nearest burrow opening was measured to the nearest $0.1 \mathrm{~m}$. Density was calculated as $D=$ $10,000 / \pi \mathrm{d}^{2}$ where $D=$ density ha ${ }^{-1}$, and $\mathrm{d}=$ mean point to burrow distance, which forms the radius of a circular area.

Harvester ant nest density and species composition was quantified along 8 strip transects, $300 \mathrm{~m}$ long x $20 \mathrm{~m}$ wide at each study site. Two people walked parallel along the transects, $20 \mathrm{~m}$ apart, for a total of 4.8 ha sampled per study site. Within this area, all harvester ant nests were counted and identified to species according to Cole (1968). Voucher ant worker collections were made and species identifications were verified by $\mathrm{Mr}$. Bobby Brown, Museum of Entomological and Prairie Arthropod Research at Kansas State University where specimens are preserved. Differentiation of species in the field was simple and accurate due to differences in size and color of workers, as well as different clearing and mound shapes among species (Table 1).

Table 1. Characteristics of the 3 species of harvester ants found at the Cimarron National Grassland in Morton Co., Kans., USA.

\begin{tabular}{llll}
\hline \hline Species & Color & Size & Mound shape \\
\hline Pogonomyrmex rugosus & black with red abdomen & large & flat \\
P. barbatus & red & large & flat \\
P. occidentalis & red & small & dome \\
\hline
\end{tabular}

At prairie dog sites, sampling transects began at the boundary of the prairie dog colony. In areas where prairie dogs were absent, sampling began at the edge of the study site. If the study site was 45 ha or smaller, the second transect was offset 75 $\mathrm{m}$ at the opposite side of the study site. At non-colonized sites, and at prairie dog colonies where the study site was larger than 45 ha, the second transect was similarly offset and started at the approximate mid-point of the site and ran in the same direction as the first. The third transect was again offset, then started at the opposite edge and ran back towards the center of the study site. This ensured that all parts of the site were thoroughly sampled as opposed to just sampling the edges or middle portions. These data were used to estimate the density of ant nests at each study site, which was the sample unit.

Total harvester ant nest density (nests $\mathrm{ha}^{-1}$ ) and species composition were compared between prairie dog colonies and non-colonized shortgrass prairie sites. Ttests were used to statistically test for differences in total harvester ant nest density, nest density of each species sampled, and harvester ant species richness between the 2 treatments $(\alpha=0.05)$. A nonparametric Wilcoxon exact test was used when deviations from normality occurred. When normality was met but variances in data were not equal among treatments a Satterthwaite t-test was used instead of Cochran t-test (SAS Inst. Inc. 1993).

\section{Results}

Black-tailed prairie dog burrow density at the 5 colonies was moderate $(\overline{\mathrm{x}}=81$, $\mathrm{SD}=56$ burrows ha $\left.^{-1}\right)$. A total of 183 harvester ant nests of 3 species was recorded. The total density of harvester ant nests did not differ significantly between prairie dog colonies and non-colonized shortgrass prairie sites (Table 2). Pogonomyrmex rugosus Emery was encountered most often and accounted for $55 \%$ of the ant nests sampled, followed by $P$. barbatus Smith (34\%), and P. occidentalis Cresson

(11\%). Although total harvester ant nest density was not significantly different on black-tailed prairie dog colonies, species composition was influenced by prairie dogs. Mean nest densities of $P$. rugosus and $P$. occidentalis did not differ significantly between treatments. However, mean species richness and nest densities of $P$. barbatus were significantly different between treatments. The nest density of $P$. barbatus was greater on study sites where prairie dogs were absent. While all 3 species of harvester ants were sampled both on and off prairie dog colonies, mean species richness was significantly greater on non-colonized shortgrass prairie sites $(\overline{\mathrm{x}}=2.6, \mathrm{SE}=0.25, \mathrm{df}=4)$ than at prairie dog colonies $(\overline{\mathrm{x}}=1.4, \mathrm{SE}=0.25, \mathrm{df}=4 ; \mathrm{P}$ $=0.0476$ ).

\section{Discussion}

Total harvester ant nest densities, as well as the density of each individual species, were lower than those reported in other studies with a variety of land-use types (Whitford et al. 1976, Soulé and Knapp 1996). On the Cimarron National Grassland, total harvester ant densities were similar to densities of $P$. occidentalis in heavily grazed pastures of northeastern Colorado (Rogers and Lavigne 1974). However, $P$. occidentalis densities on the 
Table 2. Total number of harvester ant nests sampled, and mean (+/-SE) nest density on prairie dog colonies (PDOG) and shortgrass prairie sites where prairie dogs are absent (NODOG) at the Cimarron National Grassland, Kansas.

\begin{tabular}{|c|c|c|c|c|c|c|}
\hline \multirow[b]{2}{*}{ Species } & \multicolumn{2}{|c|}{ Number of Nests } & \multicolumn{2}{|c|}{ Mean Density } & \multirow{2}{*}{\multicolumn{2}{|c|}{$\mathrm{P}$-value and test }} \\
\hline & PDOG & NODOG & PDOG & NODOG & & \\
\hline & & & $---\cdots--$ & ------ & & \\
\hline Pogonomyrmex rugosus Emery & 64 & 36 & $2.67(1.46)$ & $1.50(0.54)$ & 0.4760 & Cochran \\
\hline Pogonomyrmex barbatus Smith & 9 & 53 & $0.38(0.19)$ & $2.21(0.65)$ & $0.0470 *$ & Satterthwaite \\
\hline Pogonomyrmex occidentalis Cresson & 1 & 20 & $0.04(0.04)$ & $0.83(0.54)$ & 0.1270 & Wilcoxon \\
\hline Total Pogonomyrmex spp. & 74 & 109 & $3.08(1.29)$ & $4.54(0.43)$ & 0.3152 & Cochran \\
\hline
\end{tabular}

*Significant at the 0.05 level.

Cimarron National Grasslands were lower than in Colorado (Rogers and Lavigne 1974) and Oklahoma (O'Meilia et al. 1982) where $P$. occidentalis has been reported previously. Nagel (1969) reported lower densities of $P$. occidentalis in Morton County, Kansas, compared to other western Kansas counties.

Livestock grazing may or may not influence ant abundance and density. Nagel (1969) suggested that mated queen $P$. occidentalis select areas of rangeland with sparse vegetation and soils with high light reflectance, typical of over-grazed areas. In the Chihuahuan Desert in southeastern Arizona, ant abundance was not affected by livestock grazing (Heske and Campbell 1991). Likewise, Kirkham (1967) did not find any differences in Pogonomyrmex owyheei Cole densities in Wyoming due to different grazing intensities over a 10-year period. Likewise, in northern Colorado, light and moderate grazing resulted in $22 \%$ and $33 \%$ increases in harvester ant colony densities, but heavy grazing reduced colony density by $87 \%$ (statistical analyses were not presented) compared to the ungrazed sites (Rogers and Lavigne 1974). In northern Colorado $P$. occidental$i$ is densities are negatively associated with vegetative succession on abandoned fields, with the greatest concentrations found in areas with abundant forbs and perennial grasses, and lower densities in late succession shortgrass stages (Costello 1944).

In northern Oklahoma, O'Meilia et al. (1982) did not detect any differences in $P$. occidentalis densities between prairie dog towns and non-colonized pastures. Because of the extreme rarity of $P$. occidentalis on prairie dog colonies and variance in numbers found on non-colonized sites, we did not detect a statistical difference between treatments in this study, however, there was a trend towards greater abundance of $P$. occidentalis nests on noncolonized shortgrass prairie sites compared to prairie dog colonies (20 vs. 1 nest encountered respectively).

Pogonomyrmex rugosus and $P$. barbatus are closely related species with a wide niche overlap. These 2 species have simi- lar habitat and forage requirements. Both species prefer seeds from grasses and forbs but will also collect a variety of other materials (Whitford et al. 1976, Hölldobler and Lumsden 1980, Gordon 1993). In New Mexico grasslands, nest densities of $P$. rugosus and $P$. barbatus were approximately 20 nests per ha in areas supporting one or both species (Whitford et al. 1976), which is higher than we found. Despite the close relationship between the 2 species, they responded to prairie dog activities in different ways. Pogonomyrmex rugosus nest density was similar between the 2 treatments; whereas, $P$. barbatus nest densities were significantly higher in areas without prairie dogs.

Harvester ant species richness was significantly lower on prairie dog colonies. Although all 3 species of ants were encountered both on and off prairie dog colonies, non-colonized shortgrass sites consistently had 2 or 3 species present, whereas only 1 or 2 species were usually found on prairie dog colonies. Pogonomyrmex rugosus was the most frequent species on prairie dog colonies where it accounted for $87 \%$ of ant colonies encountered, as opposed to $33 \%$ where prairie dogs were absent. Pogonomyrmex barbatus was the most abundant species on non-colonized areas, making up $49 \%$ of the ant nests sampled there. Pogonomyrmex barbatus and P. occidentalis were nearly absent from prairie dog colonies. Pogonomyrmex barbatus was 5 times as frequent and $P$. occidentalis was 20 times more frequent on non-colonized prairie sites.

Crist and Wiens (1994) reported reduced seed harvesting of $P$. occidentalis in shortgrass pastures occupied by prairie dogs. They attributed this pattern of lower seed removal to the presence of shorthorned lizards (Phrynosoma douglassi Bell) on prairie dog colonies, rather than to the vegetative structure of those sites. Whitford and Bryant (1979) and Munger (1984a, 1984b) demonstrated that horned lizard (Phrynosoma cornutum Harlan) predation decreases the foraging activity of harvester ants. However, we do not believe that a reduction in foraging activi- ty of these ants, due to predation by horned lizards, is responsible for the observed decrease in species richness or in $P$. barbatus and $P$. occidentalis densities found on prairie dog colonies during this study. In a concurrent study in 1997, there was no difference in relative abundance of horned lizards between prairie dog colonies and non-colonized shortgrass prairie sites (Kretzer and Cully in press).

Our results are that prairie dog colony habitats are marginal, or unattractive to $P$. barbatus and $P$. occidentalis, but are attractive to $P$. rugosus. We do not know what factors are responsible for these species differences. Long-term disturbance by black-tailed prairie dogs alters plant community structure (Bonham and Lerwick 1976, O'Meilia et al. 1982, Coppock et al. 1983, Agnew et al. 1986, Archer et al. 1987, Winter 1999). Harvester ants exploit patchy but relatively stable food supplies (Hölldobler and Lumsden 1980). It is possible that changes in vegetative composition and cover, that result from prairie dog activities affect soil characteristics, food availability, and suitable nest sites in ways that have a negative influence on densities of $P$. barbatus and $P$. occidentalis with concomitant reductions in harvester ant species richness.

Black-tailed prairie dogs are known to alter the distribution, abundance, and species composition of a wide variety of plant and animal groups (Agnew et al. 1986, Archer et al. 1987, Koford 1958, Bonham and Lerwick 1976, Coppack et al. 1983, Ingham and Detling 1984, O’Meilia et al. 1982, Miller et al. 1990, Miller et al. 1994). Prairie dogs create patches of habitat that differ from the surrounding grasslands and add heterogeneity to shortgrass prairie landscapes (Whicker and Detling 1988, 1993). Our results show that prairie dogs influence closely related ant species in dramatically different ways. They also demonstrate that it is inappropriate to make broad generalizations about the positive or negative influences that prairie dogs have on other grassland organisms. 


\section{Literature Cited}

Agnew, W., D. W. Uresk, and R. M. Hansen. 1986. Flora and fauna associated with prairie dog colonies and adjacent ungrazed mixedgrass prairie in western South Dakota. J. Range Manage. 39:135-139.

Archer, S., M. G. Garret, and J. K. Detling. 1987. Rates of vegetation change associated with prairie dog (Cynomys ludovicianus) grazing in North American mixed-grass prairie. Vegetatio 72:159-166.

Bonham, C. D. and A. Lerwick. 1976. Vegetation changes induced by prairie dogs on shortgrass range. J. Range Manage. 29:221-225.

Cole, A. C. 1968. Pogonomyrmex harvester ants; a study of the genus in North America. Univ. Tennessee Press, Knoxville, Tenn.

Cook, C. W. and J. Stubbendieck. 1986. Range research: basic problems and techniques. Soc. for Range Manage., Denver, Colo.

Coppack, D. L., J. E. Ellis, J. K. Detling, and M. I. Dyer. 1983. Plant herbivore interactions in a North American mixed-grass prairie. II. Responses of bison to modification of vegetation by prairie dogs. Oecologia 56:10-15.

Costello, D. F. 1944. Natural revegetation of abandoned plowed land in the mixed prairie association of northeastern Colorado. Ecol 25(3):312-326.

Crist, T. O. and J. A. Wiens. 1994. Scale effects of vegetation on forager movement and seed harvesting by ants. Oikos 69:37-46.

Dickey, H. P., W. R. Swafford, and O. L. Markley. 1963. Soil survey of Morton County, Kansas. USDA. Soil Survey Series 1960, No. 8.

Gordon, D. M. 1993. The spatial scale of seed collection by harvester ants. Oecologia 95:479-487.

Heske, E. J. and M. Campbell. 1991. Effects of an 11-year livestock exclosure on rodent and ant numbers in the Chihuahuan Desert, southeastern Arizona. Southw. Natur. 36(1):89-93.

Hewitt, G. B., E. W. Huddleston, R. J. Lavigne, D. N. Ueckert, and J. G. Watts. 1974. Rangeland Entomology. Range Science Series No. 2. Soc. for Range Manage., Denver, Colo.

Hölldobler, B. and C. J. Lumsden. 1980. Territorial strategies in ants. Sci. 210:732-739.

Hoogland, J. L. 1995. The black-tailed prairie dog: social life of a burrowing mammal. University of Chicago Press, Chicago and London.

Ingham, R. E. and J. K. Detling. 1984. Plantherbivore interactions in a North American mixed-grass prairie. Oecologia 63:307-313.

Jacot, A. P. 1936. Soil structure and biology. Ecol. 17:359-79.

King, J. 1955. Social behavior, social organization, and population dynamics in a blacktailed prairie dog town in the Black Hills of South Dakota. Contrib. Lab. Vert. Biol 67. Univ. Michigan, Ann Arbor, Mich.
Kirkham, D. R. 1967. Harvester ant (Pogonomyrmex owyheei Cole) abundance in relation to grazing, vegetation and soil in north-central Wyoming. Unpubl. M.S. Thesis, Univ. Wyoming. Laramie, Wyo.

Koford, C. B. 1958. Prairie dogs, whitefaces, and blue grama. Wildl. Monogr. 3.

Kotliar, N. B., B. W. Baker, A. D. Whicker, and G. Plumb. 1999. A critical review of assumptions about the prairie dog as a keystone species. Environ. Manage. 24:177-192.

Kretzer, J. E. and J.F. Cully, Jr. (In Press) Black-tailed prairie dog effects on reptiles and amphibians in Kansas shortgrass prairie. Southw. Natur.

Miller, B., G. Ceballos, and R. Reading. 1994. The prairie dog and biotic diversity. Conserv. Biol. 8:677-681.

Miller, B., C. Wemmer, D. Biggens, and R. Reading. 1990. A proposal to conserve black-footed ferrets and the prairie dog ecosystem. Environ. Manage. 14:763-769.

Munger, J. C. 1984a. Optimal foraging? Patch use by horned lizards (Iguanidae: Phrynosoma). Am. Nat. 123:654-680.

Munger, J. C. 1984b. Long-term yield from harvester ant colonies: implications for horned lizard foraging strategy. Ecol. 65:1077-1086.

Nagel, H. 1969. Western harvester ants in Kansas: colony founding, nest structure and function, factors affecting density, and effect on soil formation. M.S. Thesis, Kansas State Univ., Manhattan, Kans.

O'Meilia, M. E., F. L. Knopf, and J. C. Lewis. 1982. Some consequences of competition between prairie dogs and beef cattle. J. Range Manage. 35:580-585.

Rogers, L. E. and R. J. Lavigne. 1974. Environmental effects of western harvester ants on the shortgrass plains ecosystem. Environ. Entomol. 3:994-997.

SAS Institute Inc. 1993. SAS/STAT* User's Guide, Release 6.03 edition, Cary, N.C.

Soulé, P. T. and P. A. Knapp. 1996. Pogonomyrmex owyheei nest site density and size on a minimally impacted site in central Oregon. Great Basin Nat.. 56(2):162-166.

U. S. D. I., Fish and Wildlife Service. 2000. Endangered and threatened wildlife and plants; 12 month finding for a petition to list the black-tailed prairie dog as threatened. Federal Register 64:14424-14428.

Whicker, A. D. and J. K. Detling. 1988. Ecological consequences of prairie dog disturbances. BioSci. 38(11):778-785.

Whicker, A. D. and J. K. Detling. 1993. Control of grassland ecosystem processes by prairie dogs, p. 18-27. In Oldemeyer, J. L., D. E. Biggins, B. J. Miller, and R. Crete (ed.), Management of prairie dogs complexes for the reintroduction of the black-footed ferret. U.S. Fish and Wildl. Serv., Biol. Rep. 13. Whitford, W. G. and M. Bryant. 1979. Behavior of a predator and its prey: the horned lizard (Phrynosoma cornutum) and harvester ants (Pogonomyrmex spp.). Ecol. 60:686-694.
Whitford, W. G., P. Johnson, and J. Ramirez. 1976. Comparative ecology of the harvester ants Pogonomyrmex barbatus (F. Smith) and Pogonomyrmex rugosus (Emery). Insectes Sociaux 23(2):117-132.

Winter, S. 1999. Plant and breeding bird communities of black-tailed prairie dog colonies and non-colonized areas in southwest Kansas and southeast Colorado. M.S. Thesis, Kansas State Univ., Manhattan, Kans.

Wuerthner, G. 1997. Viewpoint: The blacktailed prairie dog-headed for extinction. J. Range Manage. 50:459-466. 